\title{
Getting comfortable: gender, class and belonging in the 'new' Port Moresby
}

Se mettre à l'aise: genres, classes et appartenance dans le nouveau Port Moresby

\section{Ceridwen Spark}

\section{(2) OpenEdition \\ Journals}

Electronic version

URL: http://journals.openedition.org/jso/7772

DOI: $10.4000 /$ jso. 7772

ISSN: $1760-7256$

Publisher

Société des océanistes

\section{Printed version}

Date of publication: 15 December 2017

Number of pages: 147-158

ISSN: 0300-953x

\section{Electronic reference}

Ceridwen Spark, "Getting comfortable: gender, class and belonging in the 'new' Port Moresby", Journal de la Société des Océanistes [Online], 144-145 | 2017, Online since 15 December 2019, connection on 15 March 2021. URL: http://journals.openedition.org/jso/7772 ; DOI: https://doi.org/10.4000/jso.7772

\section{(c) (i) $\odot$}

Journal de la société des océanistes est mis à disposition selon les termes de la Licence Creative Commons Attribution - Pas d'Utilisation Commerciale - Pas de Modification 4.0 International. 


\section{Getting comfortable: gender, class and belonging in the 'new' Port Moresby}

by

Ceridwen SPARK ${ }^{*}$

\begin{abstract}
Port Moresby is consistently represented as a place that is dangerous for women. While recent transformations in the city have benefited some more than others, developments in the city are allowing for the creation of new 'spatial texts' in a place notorious for constraining women. In this article, I explore feminist geographer Linda McDowell's idea that the city is a place in which the active, independent woman comes into her own. Drawing on focus groups, emails and photos sent to me by educated, 'middle class' Papua New Guinean women living in Port Moresby, I demonstrate that the city's new places are paradoxical, even liberating places. The article reveals both the extent of women's subordination in the city and the emerging possibilities for middle class women to experience a degree of autonomy. Nevertheless as Radice notes, women must endlessly renegotiate their experience of comfort in relation to others, including those whose lives are less comfortable.
\end{abstract}

Keywords: Port Moresby, gender, class, comfort, colonialism, autonomy

\section{Coming Out}

"I think there is a lot more of us out there because there are more places where you can meet up and be more comfortable." (Jo, aged 33, administrative assistant, Port Moresby, 2015)

In 2007, I interviewed young women living in towns in Papua New Guinea. The majority had been educated overseas, whether during their secondary school years or while at university

\section{RÉSUMÉ}

Port-Moresby est régulièrement présentée comme un endroit dangereux pour les fermmes. Même si certaines bénéficient plus que d'autres des transformations récentes qui ont eu lieu en ville, les développements en ville favorisent l'essor de nouveaux espaces urbains dans une ville qui restreint le mouvement des fermmes. Dans cet article, jexplore lidée de la géographe féministe Linda McDowell suivant laquelle la ville est un espace où la fermme active et indépendante peut sépanouir. En recourant à des groupes de discussions, des mèls et des photos envoyés par des fermmes éduquées de la classe moyenne de Port-Moresby, je montre que les nouveaux espaces urbains sont des lieux paradoxaux, si ce n'est de libération. L'article montre à quel point les fermmes de la ville sont contrôlées et comment les fermmes de la classe moyenne peuvent obtenir un certain degré d'autonomie. Cependant, comme le montre Radice, les fermmes doivent constamment renégocier l'impression de confort quelle acquièrent avec d'autres, y compris avec les gens dont la vie est moins confortable que la leur.

Mots-Clés : Port Moresby, genre, classe, confort, colonialisme, autonomie

(Spark, 2010 and 2011). One of those I spoke with was Jo, from whom the above quotation comes. In August 2015, during a visit to Port Moresby, I again spoke with Jo and three of the other educated women who participated in the original research. In a private room at the top of the Grand Papua Hotel, we talked about life in Port Moresby, including the women's experiences of the city's emerging spaces and places.

This conversation makes clear that it is no longer possible to represent Moresby as a place 
that is only ever hostile to women. International media representations of Moresby as the most dangerous city in the world' highlight the inhospitable nature of this environment and the challenges faced by women in the city (see for example http://www.vladsokhin.com/work/ crying-meri). An emphasis on the dangers of the city for women is also evident in contemporary research by UN Women conducted as part of its Safe Cities programme (see UN Women, 2012). This research has led to a greater understanding of the effects of violence on women and girls in Port Moresby's markets. Nevertheless, it has done little to elucidate some of the other places that are meaningful in the ebb and flow of the lives of women in Port Moresby who do not make a living in the markets. Moreover, where women in market places:

"are always watched by men because very concrete dangers are involved in trading, such as fights about prices and theft" (Beer, 2008: 101),

professional women in Port Moresby are increasingly able to move into and between places deemed safe, thus enhancing their opportunities for independence.

In this article, I consider educated and employed Papua New Guinean women's interactions with Port Moresby. My purpose is to expand the scope of research and writing about gendered experiences in this oft-maligned city. Drawing on three focus group discussions and on photos and comments about Moresby sent to me by my friend Karuka, I consider how gender, class and colonialism are shaping the experiences of this cohort. This also reveals how Moresby is itself being shaped by women's "coming out" into the malls, parks and cafes that are proliferating as a result of PNG's resources boom. Connell argues that the urban centres of Melanesia: "attest to the failures of postcolonial development."
(Connell, 2003: 245)

In contrast, I am cautiously optimistic, suggesting that the city's new places offer women a degree of freedom and autonomy in a city predominantly characterized by fear and restriction (Spark, 2014).

The article is situated within a developing body of work that reflects the increasing ethnographic interest in Melanesian urbanity. It seeks to challenge what Connell and Lea (1994) call the "anti-urban bias" in the Pacific, a perspective that continues to be espoused including among some of Moresby's inhabitants. In addition, I critique the idea that spaces outside the home are only and always dangerous for women $(\mathrm{McD}$ Dowell, 1999; see also Tyner, 2012 and Beebe et al., 2012). This is a challenging argument to make with regard to Port Moresby, a city in which women are almost exclusively represented as victims of public and private violence. But it is a necessary one for even in this much maligned city, women experience a diversity of relationships with places and are not only ever "endangered" and "at risk".

In contrast to the containment and restriction that many women associate with home, urban women's economic freedom brings them out into the city to meet with friends, see movies or visit shops. Thus, as McDowell argues, city spaces outside the home are associated with the possibility of

"transgressing hegemonic versions of [gender and] sexuality.” (McDowell, 1999: 156)

Offering women the chance to experience a degree of liberation from the private, confining and often violent space of "home", some of Moresby's new spaces are places in which

"the active independent woman [comes] into her own." (McDowell, 1999: 155)

As middle class women access new and secure places, moving between these in their own cars or as passengers in vehicles provided by their employers, they experience a degree of freedom. While this freedom relies on insulation from the city's "others", it simultaneously enables new modes of place inhabitation in which women are arguably better situated than their grass roots counterparts who must continue to rely on family members for protection. Nevertheless: '[f] eeling comfortable with the city is never finalized; it must be endlessly renegotiated as long as the doubts lurk' (Radice, 1999: 88). Doubts do lurk in the minds of Moresby's women, including about their fellow inhabitants who are less well off and their own right to enter and be 'comfortable' in some of the city's places. These too are considered below. But first, in order to better understand the city, it is necessary to describe some of the recent changes that have taken place there.

\section{"No longer the sleepy hollow"}

Those who live in Moresby delight in informing prospective visitors that the city is no longer 'the sleepy hollow' (email to author, Steve Sims, July 2015) of times past. As Marie wrote in 2015: 'Moresby has changed, there are more roads, there is a bigger airport, and there are a lot more people in the city, the city is more connected by roads and is moving at a faster pace' (email to author, 19 August 2015). Moreover, where once the city was a place from which Papua New Guineans were: 
"physically and socially excluded except as workers" (Oram, 1976: 27)

in today's Port Moresby Papua New Guineans of diverse origins inhabit the city not only as workers but as consumers, leisure seekers, home buyers and exercisers.

Like most cities preparing to host large, internationally televised events, Moresby underwent considerable development of infrastructure during the lead up to the 2015 South Pacific Games. This included upgrades to major sporting stadiums, such as the Rita Flynn Netball Stadium, the Sir Hubert Murray Stadium and the Sir John Guise Precinct, renovation of the international airport and the construction of the "Kumul Flyover", a four lane highway which cost 161 million PNG Kina (58 million USD). The boom in the country's resources sector preceded the games, producing an increased demand for the development of more local business and commercial spaces. Between 2011 and 2014 the city saw the construction of the Malaysian owned Vision City mall, the Waterfront Food world retail complex, the Grand Papua Hotel and the Waigaini Central Shopping Complex (which includes 'Stop'n'Shop) and the Paradise movie complex. On a smaller scale, Duffy, a popular cafe which opened in Gordons in 2012 now has cafes at two additional locations, one at Harbour City, and the other in the departures area of the international airport (for a discussion of Duffy, see Spark, forthcoming, 2017). Major developments at Ela Beach and the construction of a luxury hotel at Vision City continue, as does the construction of apartments and houses all over the city.

Alongside the development of these commercial, office and residential spaces, there have been upgrades to activity and leisure sites, including Nature Park (previously the National Capital Botanical Gardens) and the Murray Barracks Leisure Centre, which now has a gym and 25 meter pool. The new Adventure Park at "14mile" has water slides and paddleboats as well as housing the National Orchid garden. PNG's National Museum and Art Gallery was also refurbished in 2015 to house a new exhibition, "Built on Culture". Alongside these changes, Powes Parkop, the Governor of the National Capital
District has overseen the construction of children's playgrounds around Moresby and implemented health initiatives, including the Sunday morning 'Walk for Life' and free yoga sessions at Murray Barracks.

These facilities and initiatives offer Moresby's educated and employed young women the opportunity to create a more expansive Port Moresby than was hitherto thought possible for their sex. To contextualise their perspectives on Port Moresby, it is worth noting some of the ways women's place in the city has been previously discussed.

Much of the research on urbanization in Port Moresby in the late 1960s and 1970s focuses on the challenges ahead for the colonial administration (see for example Harre, 1973; Oram, 1976; May, 1977) and subsequently, the newly Independent nation. In particular, ethnic differences between the town's growing numbers of inhabitants are portrayed as presenting a challenge to the development of a strong corporate identity. Moreover, in these studies, life in town tends to be represented primarily if not exclusively in relation to men's experiences and perspectives. This is so even among women researchers. Marilyn Strathern's No Money on our Skins (1975), for instance, provides a detailed account of the lives of Hagen men in Port Moresby. A few references to girlfriends and wives offer only limited insight into the lives of women. Similarly, Dawn Ryan's (1977) description of the Toaripi in Port Moresby and Lae reveals little to nothing about the lives of women migrants. Oeser's (1969) account of urban adaptation among women in Hohola provides more insight into the transition of women from village to town life, but its 
outdated assessments of women's coping mechanisms, as measured by their capacity to adapt to domestic tasks and raise their children in ways that mirror the expatriate population, render her analysis of limited value today.

Nevertheless, taken together, these studies, alongside Whiteman's (1973) monograph about Chimbu family relationships in Port Moresby, do reveal two key things about the ways in which women in town were viewed. On one hand, women are depicted as necessary recruits, because without women the ever-growing male population is described as prone to drinking and fighting. On the other, women who come to Moresby as wives are portrayed as having insufficient work and purpose and thus as vulnerable to temptations such as gambling. As Whiteman (1973: 139) writes:

"The lot of the wives in Port Moresby, many of whom came to town of their own accord, was much less satisfactory than that of the husbands, particularly if they had no brothers or close male relatives to guard their interests and provide emotional support. Only a few obtained paid employment; the others were completely dependent upon their husbands for economic support in a manner that never existed in Chimbu. This reduced their status in the husbandwife relationship."

In contrast to women "without roles" who are portrayed as maladaptive in the urban context, women who are gainfully employed are depicted as well-suited to life in Moresby. More recent research by Martha Macintyre (2011), Laura Zimmer-Tamakoshi (1993; 1998), Fiona Hukula (1999; 2012) and Melissa Demian (2017) develops this theme, offering insight into the ways in which sub-categories of Melanesian women experience the city. Nevertheless, there remains ample room for further discussion.

In what follows, I elucidate how women move in and between Moresby's new spaces and places, highlighting the comfort that they are creating and experiencing in their own right and to some extent on their own terms, rather than as subordinates of the city's male inhabitants. To do so, I draw on three sources of data that concretise the relationship between the spatial and social worlds. These are described in more detail below.

\section{Research Approach and Methods}

As noted above, I first met Jo in 2007 when I interviewed educated Papua New Guinean women about their lives. Since this time, I have maintained contact with some of the women who took part in the original research, while also expanding my contacts among the networks of other professional women in Port Moresby. In
2013, I interviewed some of the young women who have taken part in this research for my research on emerging women leaders in Melanesia and others as part of my research on the PNG women's magazine Stella (see www.stellamag.com).

Between 2012 and 2015, I visited Port Moresby on multiple occasions and was thus witness to the rapid development the city occurring at this time. Often I would meet women involved in my research at some of the new locations, including, for example, 'poolside' at the Grand Papua and more recently at Duffy and "The Edge" cafes at Harbourside. On visits to the outskirts of the city I have seen the development of large housing estates and on the way to Pacific Adventist University, observed the construction of Adventure Park, travelled on the new roads and appreciated the colourful statues erected for the Pacific Games. Between 2011 and 2016 I watched the transformation of Vision City, which has evolved from being an unnervingly quiet space, zealously guarded by security, to a bustling and seemingly more inclusive place in which a diversity of Papua New Guineans spend time. Through reading Stella magazine and speaking with a range of people I have learned about new venues around the city - places where women feel free to "dress up", where couples hold hands in public and where women exercise without fear of harassment.

Interested in how Moresby's educated and professional women were experiencing these new places and modes of being in them, I invited some of those I know to take part in focus group discussions about life in Moresby, including their perspectives on the city's new places. I conducted these focus groups in August and October 2015 at the Grand Papua and Holiday Inn Hotels respectively. There were four women in each group. Of these, I have interviewed seven of the eight before. In addition to this focus group, I also draw on a focus group discussion I conducted in Melbourne in 2013 with three Papua New Guinean women. While this was centred on gaining insight into their perspectives on Stella, the women also reflected on the relationship between changing dress styles and some of Moresby's new places. I also explore Marie and Kamalia's email responses to my questions about life in Moresby. As with the majority of the women who have taken part in this research, I first met both women in 2007.

In addition to the above and in order to add an innovative photographic dimension to my research, I also draw here on photos and commentary sent to me by my friend Karuka. Having been born and grown up in Port Moresby, Karuka now lives in New Zealand. In late 2015, when I heard Karuka was returning to Port Moresby for the first time in three years, I asked her to send me photos and comments about the city 
as she experienced it during her three week visit. She did so using "whatsapp" and later collated a powerpoint with accompanying commentary. I reference this in the following discussion.

Allowing unique insight into professional, "middle class" women's perspectives on Moresby's new spaces and places, the points of view captured here reveal the double-sided nature of some of these emerging places. On one hand, the high cost of the city's new cafes and hotels suggests that the contemporary urban experience gives (only) those with money

"the aura of freedom of choice." (Harvey, 2008: 31)

On the other, the young women's reflections serve as a reminder that spaces are

“extraordinarily complicated." (Rose, 1993: 155)

Producing a range of meanings, the city's new places are simultaneously indicative of capital's power to:

"remake the Port Moresby landscape" (Oxford Business Group, 2014: 183)

and of the less predictable transformations of identity that changes in place produce as a result of the inextricable interaction between bodies and places (Casey, 1993, 1996).

\section{Going raun raun: Young women's perspectives on 'the new Moresby'}

During her time in Moresby, Karuka visited many of the places that other professional women discuss as being representative of Moresby's transformation. This includes Vision City Mega Mall, the shopping complex constructed by Malaysian logging company, Rimbunan Hijau, and a smaller center at Harbour City. While shopping malls and cinema complexes represent the global spread of cosmopolitan consumerism (see Barbera et al., 2015) for Moresby's middle class women, they can also underpin and enable modes of being that subvert conventional constructions of women and their roles. The pessimistic view of contemporary network capitalism is that it colonises our life worlds, introducing

"the objectifying logic of the economy into everyday life." (Vendenberghe, 2013)

\section{But as Manzo (2005: 85) argues, while}

"the sociological view of malls is for the most part univocal and negative", in malls, as in any setting, people find ways to make the setting "their own" (Manzo, 2005: 88-89). Focusing on the complexity of places, it is possible to see that Vision City gives local people an opportunity to define themselves outside the regular constraints of their everyday social worlds. On entering Vision City mall, for instance, women become something other than daughters, mothers or wives; as consumers and potential consumers they are placed within transnational networks (Castells, 1996), a construction which is attractive to Moresby's women, including because it enables them to escape, albeit momentarily, some of the demands they associate with home.

As Karuka's comments make clear such places also provide options in a city where people previously had none. Discussing her photos of the Harbour City shopping complex, she writes:

"Not really a shopping complex. It's just 1 level, with a supermarket, a hair salon and also has chemist/ pharmacy etc. Like a mini plaza with the necessary shops, including Post office and a furniture shop. The furniture shop was a surprise for me, since Courts had a monopoly for years. Seeing this made me happy even though the prices were still high. It meant though that, in the coming years competition may result in people probably getting affordable furniture. Something that is lacking a lot back home. This place was a little more quieter [than Vision City] but definitely is considered a 'mall' by some. Because in the past, we used to 'hang out' at department stores like svs, etc. on the weekends if we wanted to go "raun raun" so this is a step up."

While acknowledging constraints, Karuka welcomes the presence of additional stores because they provide local people with a sense of options. This includes having somewhere safe to go and "hang out", a point I discuss in more detail below. Having options constructs residents as "citizen consumers" (Crocker, 2008), while simultaneously connecting Papua New Guineans to a world beyond Moresby, a connection which is particularly valued by women who have spent time overseas (Spark, 2010 and 2011). As Foster (2008: 170-171) notes, consumer-citizens 'need not be restricted to their own countries of political citizenship'. Rather, their concerns 'open up a new space for the creation of transnational alliances and deterritorialized communities in which some of the inequities of neoliberal economic globalization can be redressed if not eradicated'.

Melissa illustrates the "local cosmopolitanism" (Radice, 2015) that can be practiced by consumer-citizens without having to leave Port Moresby. As noted below, she appreciates being able to choose between different restaurants, commenting that this represents a change from the past. 
"If we have conversations with other people, like 'Holiday Inn has the best buffet' and I'm like 'no try Grand Papua it has a better selection', all this stuff where you can actually enjoy the fine things in life in Moresby without having to travel, [I] get my children exposed to this kind of lifestyle as well [...] We started last year where every Saturday evening we'd pick a different restaurant so we'd go either to a hotel for dinner or a Chinese restaurant cause the kids love Chinese now and these are things that my parents couldn't take us to because there were no restaurants at that time and if there was, it was at one hotel and it would be so expensive. So we can give our children that exposure." (Melissa, aged 34, lawyer, Port Moresby, 2015).

Melissa also mentioned that being out and about including with children was "becoming a norm now", adding:

"When I speak to my sister or my friends who have kids, they're doing the same thing. They're taking their kids out to the pool, on the weekend, going for lunches at the hotel or the movies [...] we're giving out children the best we can and as we can afford to."

As a result of Moresby having "changed so much", Melissa said:

"it almost feels no different if you live in Sydney or Port Moresby."

Marie echoed this, saying that she believes

"you can travel the world and still call Moresby home [and that] she feel[s] comfortable in Moresby wherever [she] is." (email to author, 19 August 2015)

Furthermore, Marie says that being able to travel and connecting with other women who have 'been outside PNG' is part of what contributes to her sense of belonging in Moresby:

"In 2007, I did see myself as an outsider because I had been educated in Australia and felt that I could not fit in easily into the culture and lifestyle in PNG. However, since that time I found that other Papua New Guineans have lived and studied abroad so I don't feel lonely anymore."

While Melissa and Marie are able to afford diverse entertainment options in (and beyond) Moresby, the capacity to purchase expensive furniture and eat in the city's restaurants eludes the majority of Moresby's citizens.

Conversely, being able to "hang out" in plazas and malls is more likely, for all citizens are "potential consumers", including people who may or may not "look the part". Indeed in this regard, women - widely perceived to be less threatening than men in public and semi-public spaces may have the advantage in accessing the more managed consumer spaces. In turn these become "spaces of pleasure" that they experience without the need to be escorted by men (McDowell, 1999: 160). This can even apply to "organised" markets, as Kamalia's words highlight:

"I do [go] but of course with other friends or with my relatives for the open markets like Boroko. I think women would go but in numbers, not by themselves. I would however go by myself or with friends to the organised ones like at Ela Beach International School or Holiday Inn or Laguna which tend to be more secure." (email to author, June 12016 )

Her response indicates the freedom and independence that managed, organized spaces afford middle class women who do not feel safe in open markets without the protection of others any more than the women that trade there do (see Sharp, forthcoming).

\section{Looking the part: well-dressed raskols and the importance of "proper footwear"}

The indeterminate nature of "looking the part" was humorously illustrated to me when a Papua New Guinean friend warned me to beware of "well-dressed rascals" at Vision City. Vision City security manager, Michael Portoglou, claims that people are "screened" before entering $\mathrm{Vi}$ sion City and that it is consequently "the safest shopping place in the city" (http://www.onepng. com/2015/09/vision-city-in-port-moresby-safefor.html).

Despite his assurances, in reality it is impossible to determine either people's class origins or who is a potential consumer and who is not. Grace, Karuka and Tabitha illustrated this in a focus group discussion about changing dress styles in PNG. Noting that Vision City is perceived as a "posh area", Tabitha said that this means that:

"even people of low socio-economic status will try to dress themselves up [...] to suit the environment."

When I asked:

"so it can be anyone going there?"

Tabitha responded:

"yes exactly [...] It's anyone going there, you know, both high and low class, but all sort of dressed to a certain theme I suppose, or standard." (Tabitha, aged 30, postgraduate student, 2013)

Dressing up is in fact one of the key pleasures for women of going to Vision City. Women in public open spaces who are wearing "skinny jeans" or "spaghetti tops" are less likely to feel comfortable because they get harassed particularly by men (see Spark, 2015). But as Grace notes: 
"Vision City has just become a safe place for a lot of people. Like the big shopping malls there, and so people are hanging around there more, and we are seeing a lot of this fashion displayed there. Like women, they feel safe, you know, they can come in their vehicles, or wherever, and then come to that place, Vision City, and then walk around and spend hours there, because it's like [...] they feel like they want to do it." (Grace, aged 31, 2013)

Grace's description of women feeling comfortable to dress up and spend hours at Vision City points toward the significance of such places as sites where the boundaries of "proper attire" are more expansive than usual. In these contexts, conservative masculine discourses about what women should wear have decreasing and limited potency (for further discussion of these issues see Cummings, 2008; Spark, 2015).

Both the impossibility of reading "class" from a person's appearance and the ways in which perceptions of class intersect with boundary-keeping masculinity are apparent in Cindy's experience of being allowed to enter one of the city's hotels one day and refused entrance by the same security guard the next.

"On Saturday we had an informal workshop so I had just turned up in my casual wear I didn't think it was different and then they stopped me at the gate and the security guard said 'yu painim wanem?' (laughs) what are you here for and I said I'm here for a workshop and he was 'no, no no you're not dressed'. So I was like 'tell your supervisor I'm coming in, open the gate', after talking, he let me come in and I made a complaint like 'why are you asking me this kind of questions' and I was carrying my laptop so I don't know what he thought I was doing there." (Cindy, aged 34, postgraduate student, Port Moresby, 2015).

On the second day Cindy chose not to dress up (she says she was wearing "shorts and a collar t-shirt"), perhaps assuming that her "laptop" would do the work of conveying her class, purpose and "right" to enter.

But as the figure of the "well-dressed rascal" illustrates, those who want to dress up are able to do so. This is especially so since the proliferation of second-hand clothes stores in PNG at which it is possible to purchase unused and designer items sent in bales from Australia and New Zealand. While maintaining a "dress code" has long served as an excuse for unofficial discrimination against Papua New Guineans seeking to enter hotels and bars (see Gammage, 2014), keeping people out has become more complex in a world in which everyone is a potential consumer. The result, in the case of the malls and second-hand shops, for example, is the creation of places in which a diversity of people of different "colours" and class backgrounds are as likely to be admitted as excluded.
While it was once widespread, Jo suggests that the idea that skin colour and clothes matter is now most likely to be perpetrated among the less educated members of Moresby society. Discussing the guards who try to read "class" from a person's clothing, she said:

"It's kind of that mentality that white people are better than your own [...] especially with security guards, because of course most security guards that are employed haven't gone past grade 8 or year 10 level of education and they haven't been exposed to you know us who can just turn up and wear whatever you know they try to stop us and say "who the hell are you'?" (Jo, aged 34, administrative professional, Port Moresby, 2015)

Quoting one-time Administrator Colonel J.K. Murray, Nigel Oram (1976: 157) noted of Port Moresby that in this context,

\section{"skin colour is taken as an infallible guide to human status, rights and potentialities."}

While legal repeals in 1963 contributed to the diminishment of discrimination in public places (Oram, 1976: 158), in reality it continues today, including in Moresby's new places from which women are sometimes excluded on the basis of what they are wearing. This seems to be particularly pronounced when places first open. For example, Jo and Cindy talked about being excluded from Paradise Cinema in the months after it opened because they didn't have "proper footwear".

However, in Jo's formulation (above), having the confidence to turn up and 'wear whatever' comes from being "exposed" to the wider world, one in which white people are not seen as "better than our own". As this example shows, where once exclusion from salubrious venues reflected racism, in contemporary Port Moresby, racist and colonialist attitudes intersect with the "hidden injuries of class" (Gewertz and Errington, 1999) and constructions of gender and belonging to position middle class women differently depending on where they are.

Discussing Airways Hotel for example, Jo said:

"Airways, OMG, it's really hard to get there even at the main gate you get asked 20 questions by the security guards, they ask you are you a guest, who are you here to see?" (Jo, aged 34, administrative professional, Port Moresby, 2015)

The women were also critical of the Port Moresby Yacht Club, describing it as having an

"old colonial style and feel [that makes them] feel uncomfortable." (Val, aged 30, postgraduate student, Port Moresby, 2015) 
Discussing the Yacht Club's fee increases, Cindy speculated that it was a way to keep people out:

"I don't know if it's deliberate but the Yacht Club over the years they've increased their fees, it used to be one grand for annual membership and then it went up to 2 grand and now it's like up to three so like every year they were raising their membership, I don't know whether it's deliberate but it attracts only certain type of people go there." (Cindy, aged 34, postgraduate student, Port Moresby, 2015)

The possibility of class exclusion is also illustrated in Karuka's photos of and comments about the pool at the Murray Barracks Leisure Centre (fig. 1). While, on the one hand she writes:

"Affordable. Anyone can enjoy. Can be accessed by public transport",

Karuka also notes that children were kept out because they

\section{"needed to be accompanied by an adult"}

but that other children who were "well dressed" were allowed in. Reflecting the ongoing significance of discrimination in contemporary Port Moresby, this situation suggests that there are a variety of ways to demonstrate being middle class - and one of them is being accompanied by parents. Another is owning a car.

\section{"It's a status thing to have your own car"}

Boundary-keeping moments arise most commonly when women approach hotels and other "gated" locations on foot. This highlights that the "car" is itself a place that confers prestige and power, protecting women from the scrutinizing gaze of (male) security guards who continue to determine access according to appearance and who are sometimes motivated to exclude women because of jealousy about their increasing power and prestige. Whether or not one owns a car is the subject of class-sensitive and sometimes arch conversations. For example, Kamalia said that the security guards where she works are baffled that she spends money on the petrol needed to drive herself to work, and encourage her to use the shuttle bus provided by their mutual employer in order to save money. Conversely, middle class women who would not consider walking or catching a PMV question those who continue to do so. Describing this, Cindy said:

\footnotetext{
"One of the questions that we increasingly get asked a lot of because we still don't [have a car] is] 'Oh you're still walking' (laughs) yes we walk and yes we still catch public transport it's not a big deal but it's a
}

status thing to have your own car." (Cindy, aged 34, Port Moresby, 2015)

Alongside status, there is another side to car ownership for women, namely the provision of a sense of safety. This also applies to women who are driven by employees as part of their position within the private sector and increasingly, the government sector. Melissa who was recently job-hunting and who has not "gotten on a PMV bus or taxi" for many years says that she and other professional women consider whether the company provides "secure transport" when applying for a job because "a lot of incidents have happened over the years".

Grace, who recently returned to Moresby after completing a Masters degree overseas, discussed the importance of safety and independence.

"The reason why I personally got or bought a car is because when I got back [from studies] I just felt first of all it was my safety, I didn't feel safe walking around or catching the bus to work or when I do other activities. And secondly [...] I'm just relying on other people and I have to plan my travel according to their schedules. I want to do things on my own I want to feel free, so the car has given me the ability to get to places and I feel secure inside. That's why I decided to get a car." (Grace, aged 31, Port Moresby, 2015)

Those who do not own a car rely on family members, "especially the boys" to drive them places. This limits their freedom of movement and the times they can be out. For instance, where Kamalia says she would drive "whenever, even late" in her "big car", Meg said she always organised to be collected by her brothers by "around nine" at night. Those without a car or company driver also utilise other strategies including having regular taxi drivers and getting off PMV buses when there are no other women on them (see also Hukula, 1999; Spark, 2014).

As with other new contexts in Moresby, the car is a "place" that can only be afforded by a few. Consequently, for some middle class women, the bus is a necessary option. Responding to my question about how she travels around the city, Marie highlights the possibility that perceptions of the bus as being an "unsafe" place may be exaggerated:

"I used to refuse to catch the bus thinking that it was too dangerous, and I would only catch taxis if I had to when working late till $6 \mathrm{pm}$. However, recently [...] I have had to start catching the bus, and I find that there is nothing wrong with catching the bus and that there are many people who catch the bus [...] I think it was all in my head, this fear of not catching public transport in Moresby and I let one incident of being held up at Gordons Market prevent me from catching the bus." (email to author, August 2015) 


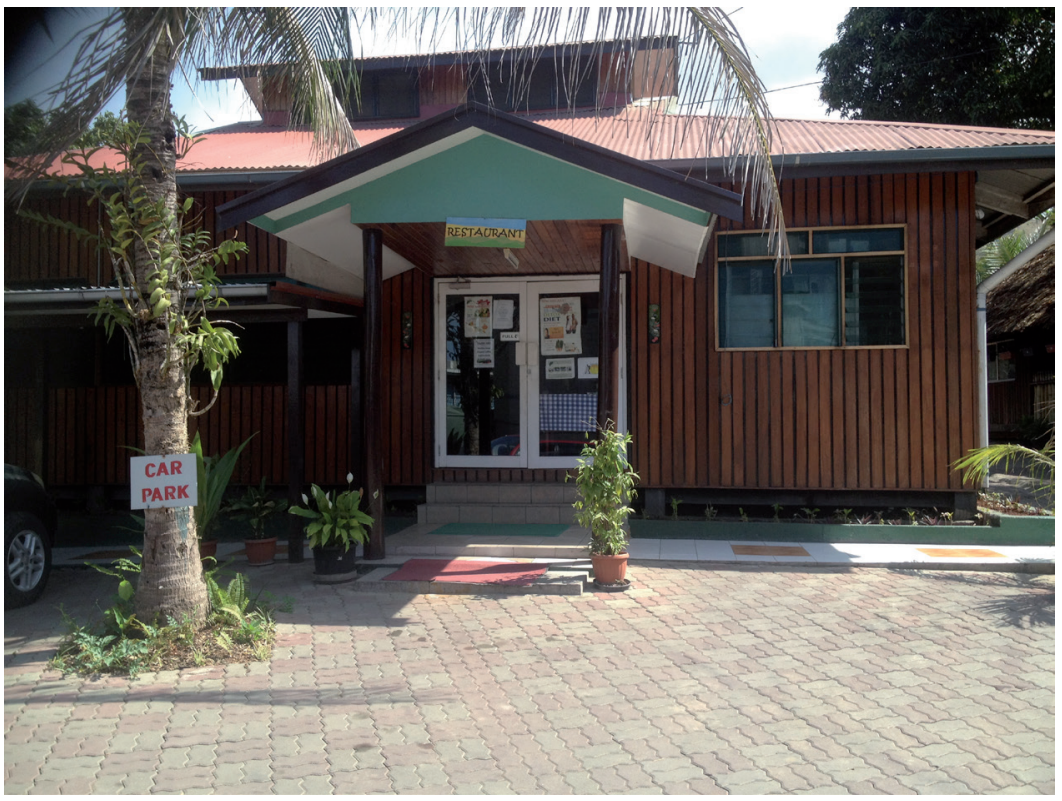

Picture 2. - Wellness Lodge, 2015 (@ Ceridwen Spark)

"the social relations of space are experienced differently, and variously interpreted, by those holding different positions as part of it." (Massey, 1994: 3)

While for some, Moresby's new places may exacerbate a sense of exclusion from the wealth generated by the country's resources boom, for others, these new locations afford the welcome experience of feeling "safe and free" (see also Hukula, 1999 who writes about the differences between employed and unemployed women).

But not all the places

Marie's reflections indicate the immense significance of the ways in which people imagine the cities in which they live.

\section{"Feeling safe and free"}

"I think for me if I'm deciding a place to go or a place to meet up with my friends the first thought that comes to my mind is ok where is the safest place to be? A place that is secure that I know that when I am sitting there that I am not conscious about someone pulling my bag or that's the sort of question that comes into my mind and usually that would be places like Vision City, Nature Park or Adventure Park." (Meg, aged 26, Port Moresby, 2015)

Meg's words demonstrate that some of the new places in Moresby - in this case Vision City, Nature Park and Adventure Park - feature prominently in women's experiences because they are perceived as secure. Similarly, in her powerpoint about Moresby, Karuka took a photo of the Edge café at Harbour City and wrote:

"I met a friend who works at ANZ, for lunch. She mentioned she only went there every two weeks etc., because it was still too costly although she loved how it was nice and relaxing and you wouldn't even think about watching your wallet or phone if you got up to view menu etc. Felt safe and free." (personal communication, Karuka, aged 34, Port Moresby, 2015)

Encapsulating the double-sided nature of some of the more expensive new places in Moresby, Karuka's comments confirm Massey's argument that: women go are considered exclusive. The women were unanimous that Vision City was a place that diverse people feel comfortable. As Joanne said:

"most people feel comfortable there; other places, people they won't like feel comfortable going [but there] everyone would feel comfortable."

As noted above, Karuka mentioned the advantage of having malls to go to just to 'hang out' and Marie said:

"having Vision City and Duffy is a relief as there are places to go to and enjoy things that you might not enjoy before."

While Karuka said that her sisters describe Duffy as a place "only money people go", Nature Park and Adventure Park are also perceived as inclusive and relatively affordable. For instance, Meg described the Nature Park entrance fee of 7 kina for adults and 4 for children as "really cheap" and said that Adventure Park was "free on weekends". The perceived affordability of Nature Park was confirmed by Karuka, who wrote alongside the photos she took at this location:

"Anyone can enjoy. Not exclusive to people with money/high status etc. despite its pleasant atmosphere i.e. café, etc."

The women also discussed some of the other ways in which Moresby was changing. For instance, considering the small playgrounds and parks created under Governor Parkop's leadership, Val said: 
"In the different suburbs we have here, he [i.e. Governor Parkop] has built places where people can go and play basketball, mini parks and the kids go back home they rush there to play, the swings and slides. It's really nice I like it, when we were going to Gerehu, people came out to play and it's safe. Before there was no one around, if I go outside someone would snatch my bag, but [with these parks] people started coming out and people started looking for each other." (Val, aged 30, Port Moresby, 2015)

Grace also talked about Parkop's 'small initiatives to get the low income population to be entertained' including:

"[a] public stage at 5 mile where popular entertainers come and sing and people just go there to watch for free."

Alongside Walk for Life and free yoga these initiatives and changes are transforming the city, helping to create new places and habits of place making that offer diverse residents opportunities to participate in the public life of the city. Letters in the Post Courier reveal residents' perspectives about these changes with some perceiving them as transformative and congratulating Parkop (June 10, 2015: 11) and others indicating that they merely represent a "band aid solution" (June 11, 2015: 11).

The most compelling evidence that Moresby is changing may be that where once women avoided being in town alone, now they come to Port Moresby to enjoy "a weekend away" because they perceive the city to be more allowing and cosmopolitan than the rest of PNG. Capturing this, Karuka described going to "Wellness Lodge" (fig. 2) to meet her friend who had come from Goroka for the weekend. Noting the Lodge's emphasis on health, including offering yoga classes for its customers, she comments:

"it seems girls are feeling more comfortable to do these things."

As noted earlier however, doubts lurk. If there is one thing about which middle class women do not feel comfortable - it is the gap between their experience of the city and that of their less well-off counterparts. Radice (1999: 134) writes:

"Feeling comfortable is a remarkably specific, yet flexible phrase. It evokes a definite sense of wellbeing, but it can apply to many situations. These range from small events in bars to the ambience of the whole metropolis, from library furniture to entire lives, from speaking a language to walking the streets [...] Crucially, it is conditional: one does not feel comfortable permanently; rather, it is a desirable state, requiring negotiation (with other 'constituents of the dwelt-inworld') in order to be maintained."

Arguably, it is precisely their negotiations with the outsider status of some of the city's "Others" that unsettles middle class women's increasing experience of comfort in Port Moresby. But I would suggest that this is not because they are seeking to differentiate themselves from kin and others in the manner identified by Gewertz and Errington (1999), but rather because they care about inequity and its increasing manifestation in their home city. Meg, for example, talked about being angry with herself for walking past people with food in her hand, noting:

"In town you want to get food from probably Steamships or Big Rooster or somewhere [but] [...] now I can't buy food and carry it and walk all the way up to the office. It's really hard because you are carrying that and you see somebody on the street looking at your food and how can I have food on me and there is somebody who doesn't have food to eat [...] Over the last three years, I've realised that so I've just stopped."

\section{Similarly, Marie wrote:}

"I met a women once who was selling fish and sago outside my office building at my old job, I wanted to be a good Christian so I took her to my building to help her sell her food. Once we got on the elevator she confessed that she had never being on an elevator before [...] I just felt for this woman as I wondered how someone would not have gotten on a lift even when she looked like she was in her late 30s. I was actually shocked and had to hold her hand and told her that everything would be fine and that it was an easier way to go up the building instead of taking the stairs."

As a result of their awareness of the gap between themselves and others, middle class women in Moresby will continue to negotiate their own experience of comfort in relation to those around them, many of whom do not share such felicitous access to the new places emerging in this rapidly changing city.

\section{Conclusion}

I have argued here that recent transformations in Port Moresby, alongside the emerging significance of education and class as markers of social status, are allowing for the creation of new 'spatial texts' in a place notorious for constraining women. As women challenge conventional boundaries of gender, asserting themselves outside the home and in the city, they redefine 'who belongs to a place and who may be excluded' (McDowell, 1999: 4), as well as the place itself. Cognisant of the need to conceptualise spaces outside the home not only as sites of surveillance, danger and harassment but also of relative freedom, I have sought to illustrate the paradoxical nature of Moresby's public, semi-public and 
commercial places in Moresby. While out and about, away from the constraints, expectations and threats that many women in PNG associate with home, middle class women can and do experience something other than containment and fear. Though they may still be channelled through a 'tunnel' (Demian, 2017) in order to get there - i.e. commuting only in locked cars or with accompanying security and not coming home 'too late' - new versions of femininity and emergent sociality are enabled by the increasing availability of places in which to practice these.

Viewing these places through a feminist lens reveals both the extent of women's subordination in the city but also the emerging possibilities for middle class women to experience a degree of autonomy. For women who have and continue to negotiate their lives and choices in relation to concerns about safety, their moral reputation, demands from husbands and other family members, these places are paradoxical if not liberating spaces. In the city's new cafes, hotels and sites of leisure, gender identities and degrees of comfort are being remapped in ways that unsettle the once more constraining social meanings and significance of place, gender and belonging in Port Moresby.

\section{REFERENCES}

Barbera Julien, John Cox and Michael Leach, 2015. The emergent middle classes in TimorLeste and Melanesia: Conceptual Issues and Developmental Significance, State, Society and Governance in Melanesia Research Discussion Paper 4, pp. 1-22.

Beebe Kathryne, Angela Davis and Kathryn GLeEdLe, 2012. Introduction: Space, Place and Gendered Identities, Feminist History and the Spatial Turn, Women's History Review 21 (4), pp. 523-532.

BeEr Bettina, 2008. Buying Betel and Selling Sex: Contested Boundaries, Risk Milieus and Discourses about HIV/AIDs in the Markham Valley, Papua New Guinea in Richard Eves and Leslie Butt (eds), Making Sense of AIDS: Culture, Sexuality and Power in Melanesia, Honolulu, University of Hawai'i Press, pp. 97-115.

Casey Edward S., 1993. Getting back into place: toward a new understanding of the place world, Bloomington, Indiana University Press.

—, 1996. The fate of place: a philosophical history, Berkley, University of California Press.

Castells Manuel, 1996. The Rise of the Network Society, Oxford, Blackwell.
Connell John, 2003. Regulation of space in the contemporary postcolonial Pacific city: Port Moresby and Suva, Asia Pacific Viewpoint 44 (3), pp. 243-257.

Connell John and John P. Lea, 1994. Cities of Parts, Cities Apart? Changing Places in Modern Melanesia, The Contemporary Pacific 6, pp. 267-309.

Crocker David A., 2008. Ethics of Global Development; Agency, Capability and Deliberative Democracy, Cambridge University Press.

Cummings Maggie, 2008. The Trouble with Trousers, in Richard Eves and Leslie Butt (eds), Making Sense of AIDS: Culture, Sexuality and Power in Melanesia, Honolulu, University of Hawai'i Press, pp. 133-149.

Demian Melissa, 2017. Making Women in the City: Notes from a Port Moresby Boarding House, Signs: Journal of Women in Culture and Society 42 (2), pp. 403-425.

Foster Robert J., 2008. Coca-Globalization: Following Soft Drinks from New York to New Guinea, New York, Palgrave Macmillan.

Gammage Bill, 2014. Moresby 1966, in Ceridwen Spark, Seumas Spark and Christina Twomey (eds), Australians in Papua New Guinea: 1960-1975, St Lucia, Queensland, University of Queensland Press, pp. 235-247.

Gewertz Deborah B. and Frederick K. ErringTON, 1999. Emerging Class in Papua New Guinea, Cambridge University Press, New York.

Harre John (ed.), 1973. Living in Town: Problems and Priorities in Urban Planning in the South Pacific, Suva, South Pacific Social Sciences Association.

Harvey David, 2008 (September-October). The right to the city, New Left Review 53, pp. 23-40.

Hukula Fiona, 1999. Women and security in Port Moresby, Boroko (Papua New Guinea), The National Research Institute, Discussion Paper, Number 92.

—, 2012. Ideas of Maleness and Femaleness in a Port Moresby Settlement, Durham Anthropology Journal 18 (2), pp. 89-96.

Macintyre Martha, 2011. Money changes everything: PNG women in the modern economy, in Mary Patterson and Martha Macintyre (eds), Managing modernity in the Western Pacific, St Lucia, Queensland, University of Queensland Press, pp. 90-120.

Manzo John, 2005. Social Control and the Management of "Personal" Space in Shopping Malls, Space and Culture 8 (1), pp. 83-97. 
Massey Doreen, 1994. Space, Place and Gender, Minnesota, Minneapolis University of Minnesota Press.

MaY Ronald James (ed.), 1977. Change and Movement; Readings on Internal Migration in Papua New Guinea, Canberra, Australian National University Press.

McDowell Linda, 1999. Gender, Identity and Place: Understanding feminist geographies, Cambridge, Polity Press.

Oeser Lynn, 1969. Hohola: the significance of social networks in urban adaptation of women in Papua New Guinea's first low cost housing estate, Canberra, Australian National University Press, New Guinea Research Bulletin 29.

Oram Nigel Denis, 1976. Colonial Town to Melanesian City, Canberra, Australian National University Press.

Oxford Business Group, 2014. The Report: Papua New Guinea 2014, Oxford Business Group.

Radice Martha, 1999. Feeling Comfortable: The Urban Experience of Anglo-Montrealers, PHD Thesis, National Library of Canada.

-, 2015. Microcosmopolitanisms at the Urban Scale, Identities: Global Studies in Culture and Power 22 (5), pp. 588-602

Rose Gilian, 1993. Feminism and Geography: the limits of geographical knowledge, Cambridge, Polity Press.

Ryan Dawn, 1977. Toaripi in Port Moresby and Lae, in Ronald James May (ed.), Change and Movement: Readings on Internal Migration in Papua New Guinea, Canberra, The Australian National University Press, pp. 147-154.

Sharp, Timothy L. M. (unpublished), Space to make a living: territory, resources and identity in Papua New Guinea's marketplaces.

Spark Ceridwen, 2010. Changing lives: understanding the barriers that confront educated women in PNG, Australian Feminist Studies 25 (63), pp. 17-30.

—, 2011. Gender trouble in town: educated women eluding male domination, gender violence and marriage in PNG, The Asia Pacific Journal of Anthropology 12 (2), pp. 164-180.

—, 2014. We only get the daylight hours: gender, fear and freedom in urban Papua New Guinea, Security Challenges 10 (2), pp. 15-32.

-, 2015. Working out what to wear in Papua New Guinea: the politics of fashion in Stella, The Contemporary Pacific 27 (1), pp. 39-70

-, Forthcoming. Hybridity in Port Moresby: Gender, Class and "a tiny bit of feminism" in Postcolonial Port Moresby, in Lia Kent, Sinclair Dinnen, Miranda Forsyth, Joanne Wallis and Srinjoy Bose (eds), Hybridity in Peacebuilding and Development: Critical Conversations, Canberra, The Australian National University Press.

Strathern Marilyn, 1975. No Money on Our Skins: Hagen Migrants in Port Moresby, New Guinea Research Institute, Canberra, Australian National University Press.

Tyner James A., 2012. Space, Place, and Violence: Violence and the Embodied Geographies of Race, Sex, and Gender, New York, Routledge.

un Women, 2012. Making Port Moresby safer for women and girls: Report on scoping study findings, Port Moresby, un Women.

Vendenberghe Frédéric, 2013. What's Critical about Critical Realism? Essays in Reconstructive Social Theory, Routledge, New York.

Whiteman John, 1973. Chimbu Family Relationships in Port Moresby, New Guinea Research Institute, Canberra, Australian National University Press.

Zimmer-Tamakoshi Laura, 1993a. Nationalism and Sexuality in Papua New Guinea, Pacific Studies 16 (4), pp. 61-97.

—, 1993b. Bachelors, spinsters and pamuk meris, in Richard Allen Marksbury (ed.), The Business of marriage: transformations in Oceanic matrimony, Pittsburgh, University of Pittsburgh Press, ASAO Monograph series, pp. 83-104.

-, 1998. Women in Town, in Laura ZimmerTamakoshi (ed.), Modern Papua New Guinea, Missouri, Thomas Jefferson University Press, pp. 195-210. 